\title{
ANTIMICROBIAL DRUG RESISTANCE IN STRAINS OF Escherichia coli ISOLATED FROM FOOD SOURCES
}

\begin{abstract}
SUMMARY
A variety of foods and environmental sources harbor bacteria that are resistant to one or more antimicrobial drugs used in medicine and agriculture. Antibiotic resistance in Escherichia coli is of particular concern because it is the most common Gram-negative pathogen in humans. Hence this study was conducted to determine the antibiotic sensitivity pattern of $E$. coli isolated from different types of food items collected randomly from twelve localities of Hyderabad, India. A total of 150 samples comprising; vegetable salad, raw egg-surface, raw chicken, unpasteurized milk, and raw meat were processed microbiologically to isolate $E$. coli and to study their antibiotic susceptibility pattern by the Kirby-Bauer method. The highest percentages of drug resistance in isolates of $E$. coli were detected from raw chicken (23.3\%) followed by vegetable salad (20\%), raw meat (13.3\%), raw egg-surface (10\%) and unpasteurized milk (6.7\%). The overall incidence of drug resistant $E$. coli was 14.7\%. A total of six (4\%) Extended Spectrum $\beta$-Lactamase (ESBL) producers were detected, two each from vegetable salads and raw chicken, and one each from raw egg-surface and raw meat. Multidrug resistant strains of $E$. coli are a matter of concern as resistance genes are easily transferable to other strains. Pathogen cycling through food is very common and might pose a potential health risk to the consumer. Therefore, in order to avoid this, good hygienic practices are necessary in the abattoirs to prevent contamination of cattle and poultry products with intestinal content as well as forbidding the use of untreated sewage in irrigating vegetables.
\end{abstract}

KEYWORDS: E. coli; Multidrug resistant; ESBL; Agriculture; Medicine.

\section{BACKGROUND}

Escherichia coli is the most prevalent facultative anaerobic species in the gastrointestinal tract of human and animals, usually a harmless microbe, but it is also a medically important bacteria causing a number of significant illnesses ${ }^{14}$.

Vegetables may be contaminated through insufficiently-treated water and fertilizers or may be compromised by the use of biocides during cultivation ${ }^{7}$. Similarly, animals can also become infected from water or food contaminated with wastes of human or animal origin or with human carrier workers. One of the possible ways of entry of various microbes could be the handling of meat and meat products by adopting improper hygienic measures during handling and processing ${ }^{20}$.

Raw meat and vegetables are particularly likely to carry large numbers of bacteria. The same E. coli and Klebsiella spp. serotypes have been found in food and in the patients who consumed $\mathrm{it}^{11,12}$ A sterile diet was shown to lower the number of E. coli serotypes found in the feces of test persons ${ }^{6}$. Bacteria escaping alive through the digestive tract to the colon are often transient ${ }^{13}$, the resident flora having a protective effect against intruders. The transfer of drug resistance within the gastrointestinal tract is still possible; thus, if our food contains substantial numbers of resistant bacteria, it could be an important source of resistance in fecal flora.

It has been suggested that resistance in bacterial populations may spread from one ecosystem to another ${ }^{18}$. The wild dissemination of antimicrobial resistance among bacterial populations is an increasing problem worldwide.

Antibiotics are often used for therapy of infected humans and animals as well as for prophylaxis and growth promotion of food producing animals. Many findings suggest that inadequate selection and abuse of antimicrobials may lead to resistance in various bacteria and make the treatment of bacterial infections more difficult ${ }^{21}$. Antimicrobial resistance in $E$. coli has been reported worldwide. Treatment for $E$. coli infection has been increasingly complicated by the emergence of resistance to most first-line antimicrobial agents ${ }^{32}$. Over the years, resistance to cephalosporins among members of enterobacteriaceae has increased mainly due to the spreading of Extended-spectrum $\beta$-Lactamases $(\mathrm{ESBL})^{40}$. 


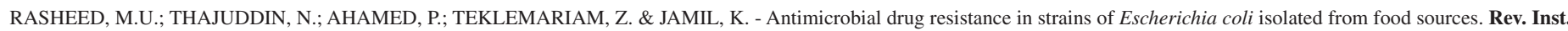
Med. Trop. Sao Paulo, 56(4): 341-6, 2014.

As commensal bacteria constitute a reservoir of resistance genes for (potentially) pathogenic bacteria, their level of resistance is considered to be a good indicator for selection pressure by antibiotic use and for resistance problems to be expected in pathogens ${ }^{24}$. Hence the aim of this study was to determine the antibiotic sensitivity pattern of E. coli isolated from different types of food items collected from in and around the Hyderabad city of Andhra Pradesh, India. The result of this study demonstrated that organisms harboring Extended Spectrum $\beta$-Lactamase (ESBL) enzymes are multi-drug resistant showing resistant to 12 or more drugs tested and thus, could pose serious challenge to the public health.

\section{METHODS}

A total of 150 samples each comprising 30 numbers; vegetable salad (carrot, cucumber, cabbage, tomatoes, spinach, lettuce, beet root and radish), raw egg-surface, raw chicken, unpasteurized milk of buffalo, and fresh raw meat of sheep were collected randomly from twelve different localities of Hyderabad. All samples were aseptically collected and then packaged in sterile polythene zip bags and carried to the laboratory in aseptic conditions in a cold box within two hours from the time of purchase. Duplicate samples were obtained whenever possible. All samples were analyzed within 2-4 hours after their arrival to the laboratory. A sharp sterile knife was used to cut samples from surfaces in sterile trays.

To isolate bacteria, a 25-g portion of samples (in case of eggs, each egg separately) was placed into sterile $225 \mathrm{~mL}$ Tryptic Soy Broth (TSB) for $6-8 \mathrm{~h}$ at $37^{\circ} \mathrm{C}$.

Culture in TSB was streaked onto MacConkey's agar (MAC) plates and incubated for $18-24$ hours at $35+2{ }^{\circ} \mathrm{C}$. Lactose fermenting colonies were picked and identified ${ }^{8}$ by gram stain, motility and standard biochemical tests, viz., catalase, oxidase, fermentation of lactose and glucose using triple sugar iron agar, production of indole, methyl red test, voges proskauer test, urease test and utilization of citrate.

Samples were also processed to isolate other medically important food borne pathogens like Salmonella spp, Staphylococcus aureus and Bacillus cereus. Biochemically confirmed isolates of E. coli were subjected to antimicrobial sensitivity testing.

Antimicrobial Susceptibility Testing: Susceptibility tests were performed using the Kirby-Bauer method on Mueller-Hinton agar in accordance with Clinical and Laboratory Standards Institute (CLSI; formerly NCCLS) guidelines (NCCLS 2002) ${ }^{26}$ and using 19 antibacterial agents: Ampicillin (10 mcg), Amoxycillin (25 mcg), Amoxyclav (20/10 mcg (30 mcg)), Aztreonam (30 mcg), Cefotaxime (30 mcg), Ceftazidime (30 mcg), Ceftriaxone (30 mcg), Chloramphenicol $(30 \mathrm{mcg})$, Ciprofloxacin (5 mcg), Colistin (10 mcg), Co-trimoxazole (1.25/23.75 $\mathrm{mcg})$, Gentamicin $(10 \mathrm{mcg})$, Imipenem $(10 \mathrm{mcg})$, Meropenem (10 $\mathrm{mcg}$ ), Ofloxacin (5 mcg), Piperacillin+tazaobactum (100/10 mcg), Streptomycin $(10 \mathrm{mcg})$, Tetracycline $(30 \mathrm{mcg})$, and Tigecycline $(15 \mathrm{mcg})$.

The $E$. coli isolates were inoculated in nutrient broth and incubated at $35+2{ }^{\circ} \mathrm{C}$ for five $\mathrm{h}$. The broth was diluted in normal saline solution to a density of $0.5 \mathrm{McF}$ arland turbidity standard. Cotton swabs were used for streaking the diluted broth onto Mueller-Hinton agar plates. After air drying, antibiotic discs were placed $30 \mathrm{~mm}$ apart and $10 \mathrm{~mm}$ away from the edge of the plate. Plates were inverted and incubated aerobically at $35+2{ }^{\circ} \mathrm{C}$ for 16 to 18 hours. The zone of inhibition and resistance was measured, recorded, and interpreted according to the recommendation of the CLSI (NCCLS 2002). The ATCC strain of E. coli 25922 was used as a control strain. All the bacteriological media and antimicrobial disks were purchased from HiMedia Laboratories, Mumbai, India. Isolates with resistance or with decreased susceptibility to any of the $3^{\text {rd }}$ Generation Cephalosporin (3GC) were selected for further study.

\section{Extended Spectrum $\beta$-Lactamase (ESBL) Confirmatory Tests}

Double Disc Synergy Test $(\text { DDST })^{17}$ : The isolated colonies were inoculated in nutrient broth at $35+2{ }^{\circ} \mathrm{C}$ for five $\mathrm{h}$. The turbidity was adjusted to $0.5 \mathrm{McFarland}$ standard and lawn culture was made on Mueller-Hinton agar using sterile swab. An Augmentin disc (20/10 mcg) was placed in the center of plate. Both sides of the Augmentin disc, a disc of cefotaxime $(30 \mathrm{mcg})$ and ceftazidime $(30 \mathrm{mcg})$, were placed with center to center distance of $15 \mathrm{~mm}$ to the centrally placed disc. The plate was incubated at $35+2{ }^{\circ} \mathrm{C}$ overnight. ESBL production was interpreted as the $3^{\text {rd }}$-generation cephalosporin disc, inhibition was increased towards the Augmentin disc or if neither discs were inhibitory alone but bacterial growth was inhibited where the two antibiotics were diffused together.

Phenotypic Confirmatory Disc Diffusion Test (PCDDT) for ESBL ${ }^{25}$ : ESBL production was confirmed among potential ESBL-producing isolates by phenotypic tests. Lawn culture of the organism was made and a $3^{\text {rd }}$-generation cephalosporins ceftazidime $(30 \mathrm{mcg})$ disc and ceftazidime + clavulanic acid (30 mcg $+10 \mathrm{mcg}$ ) disc was placed with $25 \mathrm{~mm}$ apart. An increase of $\geq 5 \mathrm{~mm}$ in zone of inhibition for ceftazidime + clavulanic acid compared to ceftazidime was confirmed as ESBL producers.

95\% confidence interval (CI) was calculated for incidence, drug resistance and ESBL production in E. coli strains. The difference in resistant and susceptibility pattern between ESBL and non-ESBL producers of $E$. coli strains results was analyzed statistically using $X^{2}$ testing and $p$ value of $\leq 0.05$ was regarded as significant.

\section{RESULTS}

A total of $99(66 \%)$ biochemically confirmed isolates of $E$. coli were isolated from a total of 150 different food items as listed in Table 1. All 99 isolates of $E$. coli tested for their antibiotic profile against 19 different antimicrobial agents.

Resistance to one or more antimicrobial agents was found in 22 (14.7\%) isolates of E. coli detected from the total of 150 samples and a pattern of multiple drug resistance was observed (Table 2). The dominant type of resistance was to ampicillin and amoxicillin identically detected in $20(13.3 \%)$ isolates, followed by tetracycline in $19(12.6 \%)$, cotrimoxazole in $17(11.3 \%)$, streptomycin in $12(8 \%)$, ciprofloxacin and ofloxacin in $10(6.6 \%)$ each, cefotaxime in $8(5.3 \%)$, and gentamicin, chloramphenicol, and amoxyclave in 7 (4.6\%) of each isolates. Twenty two $E$. coli isolates elicited 18 different patterns of antibiotic resistance to the agents used in this study (Table 2). None of the isolate was found resistant to imipenem, tigecycline and colisitin.

Of the 22 isolates of E.coli, eight were screened according to CLSI guidelines and selected for conformational tests of ESBL, namely, DDST 


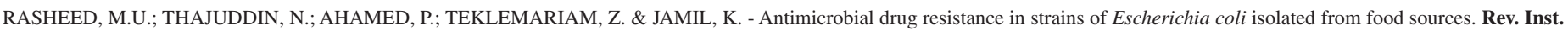
Med. Trop. Sao Paulo, 56(4): 341-6, 2014.

Table 1

Incidence of drug resistant $E$. coli from food items

\begin{tabular}{|c|c|c|c|c|c|}
\hline S. No. & Type of food & No. of samples & $\begin{array}{c}\text { Incidence of } \\
\text { E. } \operatorname{coli}(\%), 95 \% \mathrm{CI} \\
\end{array}$ & $\begin{array}{c}\text { Incidence of drug resistant } \\
\text { E. coli }(\%), 95 \% \text { CI }\end{array}$ & $\begin{array}{l}\text { Incidence of ESBL Producers- } E \text {. } \\
\text { coli }(\%), 95 \% \mathrm{CI} \\
\end{array}$ \\
\hline 1 & Vegetables salad & 30 & $\begin{array}{c}23(76.7) \\
57.71-90.06 \\
\end{array}$ & $\begin{array}{c}6(20) \\
7.71-38.56 \\
\end{array}$ & $\begin{array}{c}2(6.7) \\
0.81-22.07 \\
\end{array}$ \\
\hline 2 & Raw egg - surface & 30 & $\begin{array}{c}18(60) \\
40.60-77.34\end{array}$ & $\begin{array}{c}3(10) \\
2.11-26.52 \\
\end{array}$ & $\begin{array}{c}1(3.3) \\
0.08-17.21 \\
\end{array}$ \\
\hline 3 & Raw chicken & 30 & $\begin{array}{c}25(83.3) \\
65.27-94.35 \\
\end{array}$ & $\begin{array}{c}7(23.3) \\
9.93-42.28 \\
\end{array}$ & $\begin{array}{c}2(6.7) \\
0.81-22.07 \\
\end{array}$ \\
\hline 4 & $\begin{array}{c}\text { Unpasteurized } \\
\text { milk } \\
\end{array}$ & 30 & $\begin{array}{c}13(43.3) \\
25.46-62.57 \\
\end{array}$ & $\begin{array}{c}2(6.7) \\
0.81-22.07 \\
\end{array}$ & $0(0)$ \\
\hline 5 & Raw meat & 30 & $\begin{array}{c}20(66.7) \\
47.18-82.71 \\
\end{array}$ & $\begin{array}{c}4(13.3) \\
3.75-30.72 \\
\end{array}$ & $\begin{array}{c}1(3.3) \\
0.08-17.21 \\
\end{array}$ \\
\hline $\begin{array}{l}\text { Total No. of } \\
\text { Samples }\end{array}$ & & 150 & $\begin{array}{c}99(66) \\
57.82-73.52\end{array}$ & $\begin{array}{c}22(14.7) \\
9.42-21.35\end{array}$ & $\begin{array}{c}6(4) \\
1.48-8.50 \\
\end{array}$ \\
\hline
\end{tabular}

Table 2

Antibiotic resistance profile of isolates of E. coli

\begin{tabular}{lcc}
\hline Non-ESBL Producers & $\begin{array}{c}\text { No. of } \\
\text { isolates }\end{array}$ & $\begin{array}{c}\text { Source of } \\
\text { food }\end{array}$ \\
\hline T & 1 & V \\
Co & 1 & RM \\
A, Amx, T & 1 & V \\
A, Amx, Co, T & 4 & C 2n, UM, RM \\
A, Amx, Co, S & 1 & E \\
A, Amx C, G,S & 1 & V \\
A, Amx, Co, S, T & 2 & C, RM \\
A, Amx, Cip, Co, G, S, T, & 1 & V \\
A, Amx, AC, Ctx, Cip, Ofx, T & 1 & E \\
A, Amx, Cip, Co, G, Ofx, S, T & 1 & C \\
A, Amx, C, Cip, Co, G, Ofx, S, T & 1 & C \\
A, Amx, Ac, Ctx, C, Cip, Ofx, S, T & 1 & UM \\
\hline
\end{tabular}

\section{ESBL Producers}

\begin{tabular}{lll}
\hline A, Amx, Ac, At, Ctx, Caz, Ctr, C, Cip, & 1 & C \\
Co, Ofx, T & & \\
A, Amx, Ac, At, Ctx, Caz, Ctr, Cip, Co, & 1 & RM \\
G, Ofx, S, T & & E \\
$\begin{array}{l}\text { A, Amx, At, Ctx, Caz, Ctr, C, Cip, Co, } \\
\text { G, Ofx, S, T }\end{array}$ & 1 & \\
A, Amx, Ac, At, Ctx, Caz, Ctr, Co, G, & 1 & V \\
$\begin{array}{l}\text { Ofx, Pit, S, T } \\
\text { A, Amx, Ac, At, Ctx, Caz, Ctr, C, Cip, }\end{array}$ & 1 & V \\
$\begin{array}{l}\text { Co, Mrp, Ofx, T } \\
\text { A, Amx, Ac, At, Ctx, Caz, Ctr, C, Cip, } \\
\text { Co, G, Ofx, S, T }\end{array}$ & 1 & C \\
\hline
\end{tabular}

V: Vegetables salad, E: Raw egg - surface, C: Raw chicken, UM: Unpasteurized milk, RM: Raw meat. A: Ampicillin, Amx: Amoxycillin, AC: Amoxyclav, At: Aztreonam, Ctx: Cefotaxime, Caz: Ceftazidime, Ctr: Ceftriaxone, C: Chloramphenicol, Cip: Ciprofloxacin, Cl: Colistin, Co: Co-trimoxazole, G: Gentamicin, Ipm: Imipenem, Mrp: Meropenem, Ofx: ofloxacin, Pit: Piperacillin-tazaobactum, S: Streptomycin, T: Tetracycline, Tgc: Tigecycline. and PCDDT. Of these eight isolates, six isolates found ESBL-positive by the DDST were also ESBL-positive by the PCDDT and the remaining two isolates found ESBL-negative by both the techniques. Thus, a 100 per cent concurrence was noted in the results obtained by the DDST and PCDDT for the eight isolates tested retrospectively. All the six strains of ESBL-producing E. coli, showed enhanced susceptibility to ceftazidime and/or cefotaxime in the presence of clavulanic acid, a typical finding for an ESBL producer.

A significant difference in resistant and susceptibility pattern was found between ESBL and non-ESBL producers of E. coli strains (Table 2 ). In all the cases $p$ value was $<0.05$. Among non-ESBL producers only two isolates showed resistant to $3^{\text {rd }}$ generation cephalosporin, cefotaxime. Whereas all six ESBL producers were resistant to all $3 \mathrm{GC}$ tested and also to aztreonam. Moreover, only ESBL producers have exhibited resistance to meropenem and piperacillin+tazobactum. Among six ESBL producers one strain was resistant to meropenem and another to piperacillin+tazobactam. All the six ESBLs were sensitive only to imipenem, meropenem, piperacillin + tazaobactum, tigecycline, colistin, chloramphenicol, gentamicin, streptomycin, ciprofloxacin and amoxyclav in different patterns.

The number of antibiotics against which each isolate showed resistance ranged between one and 14. Among the non-ESBL producers, two were exhibited resistant to two different single antibiotics (Tetracycline and Co-trimoxazole respectively), six were found to be resistant to less than five antibiotics, five showed resistance to 5-7 antibiotics and three showed resistance to 8-9 antibiotics. In case of ESBL producers, one isolate was resistant to 12 antibiotics, four to 13 antibiotics and one to 14 antibiotics.

\section{DISCUSSION}

Antimicrobial resistance has been recognized as an emerging worldwide problem in human and veterinary medicine ${ }^{2,10}$ both in developed and developing countries. It is also well documented that widespread use of antibiotics in agriculture and medicine is accepted as a major selective force in the high incidence of antibiotic resistance among gram-negative bacteria ${ }^{23}$. A variety of foods and environmental sources 


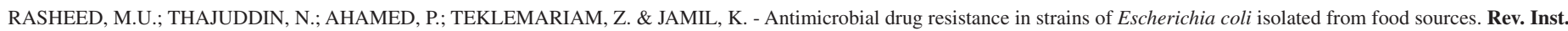
Med. Trop. Sao Paulo, 56(4): 341-6, 2014.

harbor bacteria that are resistant to one or more antimicrobial drugs used in human or veterinary medicine and in food-animal production ${ }^{3,5}$.

Several studies have documented the drug resistant E. coli and other coliforms in vegetables ${ }^{29}$, poultry ${ }^{18}, \operatorname{egg}^{4}$, milk $^{9}$ and raw meat ${ }^{35}$.

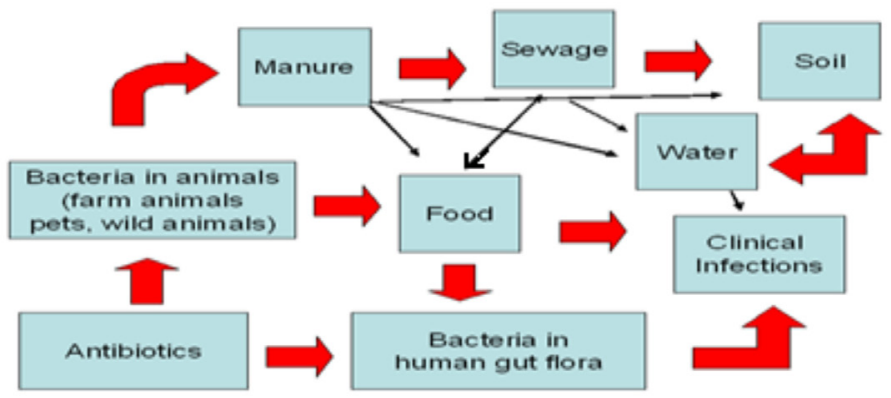

Fig. 1 - Antibiotic resistance flow chart in bacteria and the environment ${ }^{36}$.

In this study, the highest percentages of drug resistance in isolates of E.coli were detected from raw chicken $(23.3 \%)$ followed by vegetable salad $(20 \%)$, raw meat $(13.3 \%)$, raw egg-surface (10\%) and unpasteurized milk (6.7\%). The overall incidence of drug resistant E. coli was $14.7 \%$.

Antibiotic resistance in $E$. coli is of particular concern because it is the most common Gram-negative pathogen in humans, the most common cause of urinary tract infections, a common cause of both community and hospital-acquired bacteraemia ${ }^{33}$ as well as a cause of diarrhea ${ }^{19}$. In addition, resistant $E$. coli strains have the ability to transfer antibiotic resistance determinants not only to other strains of E.coli, but also to other bacteria within the gastrointestinal tract and to acquire resistance from other organisms ${ }^{28}$.

Different use patterns of antimicrobial agents are expected to have some impact on the distribution of antimicrobial resistance phenotypes ${ }^{1,22}$ and possibly of resistant determinants. The result of the antibiotic resistance analysis revealed that among 16 non-ESBLs, only four and two isolates had similar antibiotic patterns to four and five drugs respectively. All the six ESBLs had different patterns of drug resistance.

Current work revealed that all the co-trimoxazole resistant isolates except one were multi-drug resistant. In E. coli, trimethoprimsulfamethoxazole resistance often correlates with the presence of dihydrofolate reductase (DHFR) and dihydropteroate synthase (DHPS) genes in integrons ${ }^{15,39}$. Multiple antibiotic resistance may be acquired through mobile genetic elements such as plasmids, transposons, and class 1 integrons ${ }^{34}$.

The number of studies describing the prevalence of ESBL-producing Enterobacteriaceae has increased rapidly around the world ${ }^{36}$. A total of six (4\%) ESBL producers were detected in this study, two each from vegetable salads and raw chicken, and one each from raw egg-surface and raw meat. No ESBL producer was detected in the unpasteurized milk.

The result of this investigation shows that organisms harboring Extended Spectrum $\beta$-Lactamase enzymes are multi-drug resistant showing resistant to 12 or more drugs tested and thus, could pose serious challenge to the public health. ESBLs are often encoded by genes located on large plasmids, and these also carry genes for resistance to other antimicrobial agents ${ }^{31}$.

In recent years, ESBL-producing Enterobacteriaceae isolates have shifted from the hospital to the community and the environment ${ }^{27}$. ESBL-producing Enterobacteriaceae have been recovered from different sources in the community, including cattle, chickens, pigs, raw milk, and lettuce ${ }^{16,30,37}$, and a recent study from India reported that a substantial number of tap water samples were contaminated with carbapenemase $b l a_{\mathrm{NDM}-1}$ producing organisms ${ }^{38}$. Most of the studies on this subject have been conducted in developed countries, but the major epicenters of ESBLexpressing bacteria are located in Asia, Africa, and the Middle East ${ }^{36}$.

\section{CONCLUSIONS}

Even though the incidence of multidrug resistant and ESBL producers were not high in our study but still it is a matter of concern, since there is a reservoir of antibiotic resistant genes within the community, and that the resistance genes and plasmid-encoded virulent genes are easily transferable to other strains. Pathogen cycling through food is very common and might pose a potential health risk to the consumer.

Therefore, cautions are necessary to decrease the incidence of multidrug resistant strains of E. coli in animals and people. In order to achieve this, good hygienic practices are necessary from the farm to the family table especially in the abattoirs to prevent contamination of cattle and poultry products and abattoir environment with intestinal content. Health authorities should focus on implementing the legislation that forbids irrigation with untreated sewage water of both root and leafy vegetables.

Furthermore, there is a need to emphasize the rational use of antimicrobials and strictly adhere to the concept of "reserve drugs" to minimize the misuse of available antimicrobials in agriculture and medicine. In addition, regular antimicrobial susceptibility surveillance is essential.

\section{RESUMO}

\section{Resistência microbiana a drogas em linhagens de Escherichia coli isoladas de fontes alimentares}

Variedade de alimentos e fontes ambientais contem bactérias resistentes a uma ou mais drogas antimicrobianas usadas em medicina e agricultura. Resistência antibiótica pela Escherichia coli é particularmente preocupante porque ela é o patógeno mais comum Gram negativo em humanos. Portanto este estudo foi conduzido para determinar o aspecto de sensibilidade antibiótica da $E$. coli isolados de diferentes tipos de alimentos obtidos ao acaso de 12 localidades de Hyderabad, India. Um total de 150 amostras compreendendo saladas, vegetais, superfícies de ovos crus, galinhas cruas, leite não pasteurizado e carne crua foram processados microbiologicamente para isolar E. coli e estudar o quadro de sensibilidade antibiótica pelo método de Kirby-Bauer. A maior percentagem de resistência à droga foi isolada de $E$. coli obtidos de galinha crua $(23,3 \%)$ seguido de saladas e vegetais $(20 \%)$, carne crua $(13,3 \%)$, superfície do ovo cru $(10 \%)$ e leite não pasteurizado (6,7\%). Incidência total de E. coli resistente foi de $14,7 \%$. Um total de seis (4\%) Extended Spectrum $\beta$-Lactamase (ESBL) produtores foram detectados, dois cada de salada de vegetais e galinha crua e um cada de superfície de ovo cru e carne crua. Espécies resistentes a múltiplas 
RASHEED, M.U.; THAJUDDIN, N.; AHAMED, P.; TEKLEMARIAM, Z. \& JAMIL, K. - Antimicrobial drug resistance in strains of Escherichia coli isolated from food sources. Rev. Inst. Med. Trop. Sao Paulo, 56(4): 341-6, 2014.

drogas de E. coli são matéria de preocupação uma vez que os genes de resistência podem facilmente ser transferidos para outras linhagens. O ciclo do patógeno é muito comum nos alimentos e pode ser risco potencial para a saúde do consumidor. Portanto, para evitar isto boas práticas de higiene são necessárias nos abatedouros para prevenir a contaminação de gado e aves com conteúdo intestinal assim como proibir o uso de águas de esgoto não tratadas para irrigar vegetais.

\section{REFERENCES}

1. Aarestrup FM. Association between the consumption of antimicrobial agents in animal husbandry and the occurrence of resistant bacteria among food animals. Int J Antimicrob Agents. 1999;12:279-85.

2. Amundsen D, Lindholm C, Goyal SM, Robinson RA. Microbial pollution of well water in southeastern Minnesota. J Environ Sci Health. 1988;23:453-68.

3. Anderson AD, Nelson JM, Rossiter S, Angulo FJ. Public health consequences of use of antimicrobial agents in food animals in the United States. Microb Drug Resist. 2003;9:373-9.

4. Arathy DS, Vanpee G, Belot G, Mathew V, DeAllie C, Sharma R. Antimicrobial drug resistance in Escherichia coli isolated from commercial chicken eggs in Grenada, West Indies. West Indian Med J. 2011;60:53-6.

5. Bager F, Helmuth R. Epidemiology of resistance to quinolones in Salmonella. Vet Res. 2001;32:285-90.

6. Bettelheim KA, Cooke, EM, O' Farrell S, Shooter RA. The effect of diet on intestinal Escherichia coli. J Hyg (Lond). 1977;79:43-5.

7. Beuchat LR. Pathogenic microorganisms associated with fresh produce. J Food Prot. 1996;59:204-16.

8. Cheesbrough M. Microbiology. In: Medical laboratory manual for tropical countries. Oxford: ELBS Butterworth-Heinemann Ltd; 1993. vol. II.

9. Cizek A, Dolejska M, Novotna R, Haas D, Vyskocil M. Survey of Shiga toxigenic Escherichia coli $\mathrm{O} 157$ and drug-resistant coliform bacteria from in-line milk filters on dairy farms in the Czech Republic. J Appl Microbiol. 2008;104:852-60.

10. Cohen ML. Changing patterns of infectious disease. Nature. 2000;406:762-7.

11. Cooke EM, Sazegar T, Edmonson AS, Brayson JC, Hall D. Klebsiella species in hospital food and kitchens: a source of organisms in the bowel of patients. J Hyg (Lond). 1980;84:97-101.

12. Cooke EM, Kumar PJ, Shooter RA, Rousseau SA, Foulkes AL. Hospital food as a possible source of Escherichia coli in patients. Lancet. 1970;1(7644):436-7.

13. Corpet DE. Antibiotic resistance from food. N Eng J Med.1988;318:1206-7.

14. Friedman ND, Kaye KS, Stout JE, McGarry SA, Trivette SL, Briggs JP, et al. Health care-associated bloodstream infections in adults: a reason to change the accepted definition of community-acquired infections. Ann Intern Med. 2002;137:791-7.

15. Huovinen P, Sundström L, Swedberg G, Sköld O. Trimethoprim and sulfonamide resistance. Antimicrob Agents Chemother. 1995;39:279-89.

16. Jakobsen L, Kurbasic A, Skjot-Rasmussen L, Ejrnaes K, Porsbo LJ, Pedersen K, et al. Escherichia coli isolates from broiler chicken meat, broiler chickens, pork, and pigs share phylogroups and antimicrobial resistance with community-dwelling humans and patients with urinary tract infection. Foodborne Pathog Dis. 2010;7:537-47.

17. Jarlier V, Nicolas MH, Fournier G, Philippon A. Extended broad-spectrum betalactamases conferring transferable resistance to newer beta-lactam agents in Enterobacteriaceae: hospital prevalence and susceptibility patterns. Rev Infect Dis. 1998;10:867-78.
18. Johnson JR, Sannes MR, Croy C, Johnston B, Clabots C, Kuskowski MA, et al. Antimicrobial drug-resistant Escherichia coli from humans and poultry products, Minnesota and Wisconsin, 2002-2004. Emerg Infect Dis. 2007;13:838-46.

19. Kaper JB, Nataro JP, Mobley HLT. Pathogenic Escherichia coli. Nat Rev Microbiol. 2004;2:123-40.

20. Kiranmayi CB, Krishnaiah N, Subhashini N, Amaravathi P, Maheswari M, Ramya P. PCR analysis of mutton and chicken samples for the presence of Shiga toxigenic E.coli. Arch Clin Microbiol. 2011;2:2-4. Available from: [http://imedpub.com/ojs/ index.php/acmicrob/article/view/272/260]

21. Kolár M, Urbánek K, Látal T. Antibiotic selective pressure and development of bacterial resistance. Int J Antimicrob Agents. 2001;17:357-63.

22. Kulkarni RK, Das GP, Dharmi S, Jamil K. Evaluation of antibiotic sensitivity and resistance of Klebsiella species from humans respiratory and urinary tract infections. Res J BioTechnol. 2007; 2(4):29-33.

23. McKeon DM, Calabrese JP, Bissonnette GK. Antibiotic resistant gram-negative bacteria in rural groundwater supplies. Water Res. 1995;29:1902-8.

24. Murray BE. Problems and dilemmas of antimicrobial resistance. Pharmacotherapy.1992;12(6 Pt 2):86S-93S.

25. NCCLS. National Committee for Clinical Laboratory Standards. Methods for dilution antimicrobial susceptibility tests for bacteria that grow aerobically. Approved standard M7-A5 and informational supplement M100-S10. Wayne: NCCLS; 2000

26. NCCLS. National Committee for Clinical Laboratory Standards. Performance standards for antimicrobial disk and dilution susceptibility tests for bacteria isolated from animals. Approved standard M31-A2. Wayne, NCCLS; 2002.

27. Okeke IN, Laxminarayan R, Bhutta ZA, Duse AG, Jenkins P, O'Brien TF, et al. Antimicrobial resistance in developing countries. Part I: recent trends and current status. Lancet Infect Dis. 2005;5:481-93.

28. Österblad M, Hadanen A, Manninen R, Leistevuo T, Peltonen R, Meurman O, et al A between-species comparison of antimicrobial resistance in enterobacteria in fecal flora. J Antimicrob Chemother.2000;44:1479-84.

29. Österblad M, Pensala O, Peterzéns M, Heleniusc H, Huovinen P. Antimicrobial susceptibility of Enterobacteriaceae isolated from vegetables. J Antimicrob Chemother. 1999;43:503-9.

30. Ramchandani M, Manges AR, DebRoy C, Smith SP, Johnson JR, Riley LW. Possible animal origin of human-associated, multidrug-resistant, uropathogenic Escherichia coli. Clin Infect Dis. 2005;40:251-7.

31. Rawat D, Nair D. Extended-spectrum $\beta$-lactamases in Gram negative bacteria. J Glob Infect Dis. 2010;2:263-74.

32. Sabaté M, Prats G, Moreno E, Ballesté E, Blanch AR, Andreu A. Virulence and antimicrobial resistance profiles among Escherichia coli strains isolated from human and animal wastewater. Res Microbiol. 2008;159:288-93.

33. Salvadori M, Coleman BL, Louie M, McEwen S, McGeer A. Consumption of antimicrobial-resistant Escherichia coli-contaminated well water: human health impact. PSI Clin Res. 2004;6-25. Available from: [http://microbiology.mtsinai.on.ca/ research/wellwaterstudy/PSI_doc_2004.pdf]

34. Singh R, Schroeder CM, Meng J, White DG, McDermott PF, Wagner DD, et al. Identification of antimicrobial resistance and class 1 integrons in Shiga toxin producing Escherichia coli recovered from humans and food animals. J Antimicrob Chemother. 2005;56:216-9.

35. Srinivasa Rao T, Gill JPS, Ravi Kumar GVVPS, Ghatak S. Multi drug resistance patterns of Shiga toxin - producing Escherichia coli (STEC) and non - STEC isolates from meats, RTE meat foods, drinking water and human diarrhoeic samples of Punjab, India. Arch Clin Microbiol. 2011;2:1-12. Available from: [http://imedpub.com/ojs/ index.php/acmicrob/article/view/256] 
RASHEED, M.U.; THAJUDDIN, N.; AHAMED, P.; TEKLEMARIAM, Z. \& JAMIL, K. - Antimicrobial drug resistance in strains of Escherichia coli isolated from food sources. Rev. Inst. Med. Trop. Sao Paulo, 56(4): 341-6, 2014.

36. Tham J. Extended-spectrum beta-lactamase-producing enterobacteriaceae: epidemiology, risk factors, and duration of carriage. Sweden: Department of Clinical Sciences/Malmö Infectious Disease Research Unit/Lund University; 2012. Available from: [http://lup.lub.lu.se/luur/download?func=downloadFile\&recordOId=3045564 \&fileOId $=3045665$

37. Vincent C, Boerlin P, Daignault D, Dozois CM, Dutil L, Galanakis C, et al. Food reservoir for Escherichia coli causing urinary tract infections. Emerg Infect Dis. 2010;16:88-95

38. Walsh TR, Weeks J, Livermore DM, Toleman MA. Dissemination of NDM1 positive bacteria in the New Delhi environment and its implications for human health: an environmental point prevalence study. Lancet Infect Dis. 2011;11:355-62.

39. White PA, McIver CJ, Rawlinson WD. Integrons and gene cassettes in the Enterobacteriaceae. Antimicrob Agents Chemother. 2001;45:2658-61.

40. Yusháu M, Umar MI, Suleiman K. Indigenous commercial drinks as potential sources of extended spectrum $\beta$-lactamases (ESBLS) producing organisms in Kano, Nigeria. Int J Biomed Health Sci. 2010;6:103-8.

Received: 5 August 2013

Accepted: 8 January 2014 